\title{
PENERAPAN HUKUM MORTALITA MAKEHAM UNTUK PERHITUNGAN NILAI TUNAI MANFAAT DENGAN TINGKAT SUKU BUNGA VASICEK DAN CIR
}

\author{
HERLIANI EVINDA, NARWEN, DODI DEVIANTO \\ Program Studi Matematika, \\ Fakultas Matematika dan Ilmu Pengetahuan Alam, Universitas Andalas, \\ Kampus UNAND Limau Manis Padang, Indonesia. \\ email: herliani.evinda@gmail.com
}

\begin{abstract}
Abstrak. Perhitungan nilai tunai manfaat memerlukan tingkat suku bunga. Tingkat suku bunga yang biasa digunakan adalah tingkat suku bunga konstan. Namun, pembayaran nilai tunai manfaat adalah pembayaran jangka panjang dengan perubahan tingkat suku bunga yang disebabkan oleh berbagai faktor seperti inflasi. Untuk itu digunakan tingkat suku bunga stokastik yang mengikuti model Vasicek dan Cox-Ingersol-Ross $(C I R)$. Perhitungan nilai tunai manfaat juga memerlukan tabel mortalita dan pendekatan hukum mortalita. Pendekatan dengan hukum mortalita digunakan karena hasil dari pendekatan tersebut berbentuk kontinu, sehingga praktis dalam penggunaannya. Salah satu hukum mortalita yang terkenal adalah hukum mortalita Makeham. Selain itu, nilai parameter pada tingkat suku bunga Vasicek dan CIR serta usia nasabah saat penandatanganan kontrak asuransi juga mempengaruhi hasil perhitungan nilai tunai manfaat.
\end{abstract}

Kata Kunci: nilai tunai manfaat, Vasicek, CIR, Makeham

$\begin{array}{lll}\text { Diterima } & : & \text { 6 Juli 2018 } \\ \text { Direvisi } & : & \text { 15 September 2018 } \\ \text { Dipublikasikan } & : & \text { 21 Desember 2018 }\end{array}$

\section{Pendahuluan}

Pada saat ini semakin banyak masyarakat yang menggunakan jasa perusahaan asuransi, salah satunya adalah asuransi jiwa. Asuransi jiwa adalah suatu upaya perlindungan yang diberikan oleh pihak penanggung terhadap risiko pada jiwa peserta asuransi yang disebabkab oleh suatu peristiwa yang tidak dapat diprediksi. Setelah mengikuti asuransi jiwa maka nasabah harus membayar premi sesuai dengan polis yang telah disetujui dan mendapatkan manfaat. Besarnya nilai manfaat tergantung atas besarnya premi yang dibayarkan [7]. Premi yang dibayarkan peserta asuransi bergantung pada usia masuknya peserta asuransi dan tingkat suku bunga [6]. Tingkat suku bunga yang biasa digunakan adalah tingkat suku bunga konstan. Pembayaran nilai tunai manfaat adalah pembayaran jangka panjang dengan perubahan tingkat suku bunga yang disebabkan oleh berbagai faktor seperti inflasi [2]. Pada penelitian ini akan dilakukan perhitungan nilai tunai manfaat dengan tingkat suku bunga stokastik yang mengikuti model Vasicek dan Cox-Ingersol-Ross (CIR). 
Dalam menjalankan bisnis asuransi jiwa, perusahaan asuransi akan berkaitan dengan suatu permasalahan yaitu terdapatnya penurunan jumlah peserta asuransi yang disebabkan oleh risiko kematian, kecelakaan, dan lain-lain. Oleh karena itu, perhitungan premi dan manfaat dihitung dengan model penyusutan majemuk [3]. Pada penelitian ini, perhitungan manfaat akan dihitung berdasarkan hukum mortalita Makeham. Hukum mortalita Makeham melibatkan parameter yang memperhitungkan risiko kematian karena faktor usia dan kecelakaan [5].

Jadi, dalam penelitian akan dilakukan perhitungan nilai tunai manfaat berdasarkan hukum mortalita Makeham dengan tingkat suku bunga konstan dan tingkat suku bunga yang mengikuti model Vasicek dan Cox-Ingersol-Ross (CIR) serta melihat pengaruh dari berbagai usia pihak tertanggung dan parameter tingkat suku bunga Vasicek dan Cox-Ingersol-Ross (CIR) terhadap nilai tunai manfaat.

\section{Nilai Tunai Manfaat Asuransi Jiwa Seumur Hidup}

Misalkan dilakukan pembayaran manfaat sebesar 1 unit pada akhir tahun ketika pihak tertanggung meninggal, yaitu pada saat $k+1$, maka fungsi peubah acak nilai tunai manfaatnya adalah

$$
z_{k+1}=1 \cdot v_{k+1}
$$

Actuarial Present Value $(A P V)$ dari $z_{k+1}$ adalah

$$
A_{x}=\sum_{k=0}^{\omega-x} \exp (-r(k+1)){ }_{k} p_{x} q_{x+k}
$$

dimana $r=\ln (1+i)$ adalah force of interest, $x$ adalah usia pihak tertanggung saat menandatangani kontrak, $\omega$ adalah usia maksimum dari suatu populasi [1].

\section{Hukum Mortalita Makeham}

Fungsi percepatan mortalita pada hukum mortalita Makeham dinyatakan dengan

$$
\mu(x)=A+B c^{x}
$$

dengan $B>0, A \geq-B, c>1$, dan $x, t \geq 0$. Parameter $A$ menyatakan risiko yang disebabkan oleh kecelakaan dan $B c^{x}$ menyatakan risiko karena faktor usia [1].

Peluang seseorang berusia $x$ tahun dapat hidup hingga $x+t$ berdasarkan hukum mortalita Makeham adalah

$$
{ }_{t} p_{x}=\exp \left(-A t-\frac{B c^{x}}{\ln c}\left(c^{t}-1\right)\right) .
$$

\section{Tingkat Suku Bunga Vasicek dan CIR}

Misalkan suku bunga dilambangkan dengan $r$ dan waktu dilambangkan dengan $t$, dan misalkan $P_{1}(t)$ menyatakan ekspektasi nilai tunai dari pembayaran sebesar 1 unit pada saat $t$ untuk tingkat suku bunga Vasicek [4]

$$
P_{1}(t)=\exp \left(\frac{\left(\frac{1-\exp (-a t)}{a}-t\right)}{a^{2}}\left(b-\frac{\sigma^{2}}{2 a^{2}}\right)-\frac{\sigma^{2}\left(\frac{1-\exp (-a t)}{a}\right)^{2}}{4 a}-\frac{1-\exp (-a t)}{a} r(0)\right)
$$


dan $P_{2}(t)$ menyatakan ekspektasi nilai tunai dari pembayaran sebesar 1 unit pada saat $t$ untuk tingkat suku bunga $C I R[4]$

$$
P_{2}(t)=\left(\frac{2 d \exp \left(\left(\frac{a+d}{2}\right) t\right)}{(d+a)(\exp (t d)+d-a}\right)^{\frac{2 a b}{\sigma^{2}}} \exp \left(-\frac{2 r(0)(\exp (t d)-1)}{(d+a)(\exp (t d)+d-a}\right) .
$$

dengan $d=\sqrt{a^{2}+2 \sigma^{2}}$, a adalah kecepatan penyesuaian suku bunga terhadap $b, b$ adalah tingkat suku bunga jangka panjang, dan $\sigma$ adalah volatilitas suku bunga.

Actuarial Present Value (APV) dari manfaat asuransi jiwa seumur hidup dengan tingkat suku bunga mengikuti model Vasicek adalah

$$
A_{x} \text { Vasicek }=\sum_{k=0}^{\omega-x} P_{1}(t)_{k} p_{x} q_{x+k}
$$

dan Actuarial Present Value (APV) dari manfaat asuransi jiwa seumur hidup dengan tingkat suku bunga mengikuti model Cox-Ingersol-Ross (CIR) adalah

$$
A_{x} C I R=\sum_{k=0}^{\omega-x} P_{2}(t){ }_{k} p_{x} \cdot q_{x+k}
$$

\section{Aplikasi Kasus}

Suatu perusahaan asuransi menawarkan produk asuransi jiwa seumur hidup dengan manfaat yang diberikan sebesar 1 unit pada akhir tahun ketika pihak tertanggung meninggal dunia dan tingkat suku bunga sebesar $5 \%$ pertahun, dengan peserta asuransi berusia 25 tahun, 35 tahun, dan 45 tahun. Tabel mortalita yang digunakan adalah Tabel Mortalita Indonesia (TMI) 3 tahun 2011 untuk pria dan Tabel Mortalita Indonesia (TMI) 3 tahun 2011 wanita.

\section{Nilai tunai Manfaat dengan Tingkat Suku Bunga Konstan}

Nilai tunai manfaat dihitung dengan menggunakan Persamaan 2.1. Hasil perhitungan nilai tunai manfaat dengan tingkat suku bunga konstan dapat dilihat pada Gambar 1 .

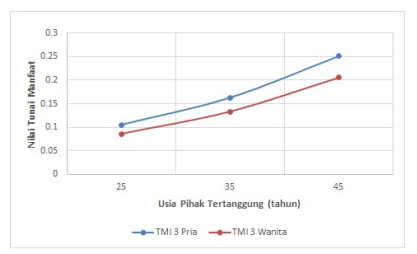

Gambar 1. Grafik nilai tunai manfaat untuk tingkat suku bunga konstan sebesar $5 \%$.

Pada Gambar 1, dapat dilihat bahwa semakin tinggi usia peserta asuransi, nilai tunai manfaat yang diperoleh juga semakin tinggi. Hal ini dikarenakan pada usia yang lebih tinggi, tingkat risiko yang mungkin dialami oleh peserta asuransi semakin besar. 


\section{Nilai tunai Manfaat dengan Tingkat Suku Bunga Konstan berdasarkan} Hukum Mortalita Makeham

Nilai tunai manfaat berdasarkan hukum mortalita Makeham dengan tingkat suku bunga konstan akan dihitung dengan menggunakan Persamaan 2.1, dengan menggunakan tabel mortalita Makeham. Berikut adalah hasil perhitungan nilai tunai manfaat dengan tingkat suku bunga konstan berdasarkan hukum mortalita Makeham yang dapat dilihat pada Gambar 2 .

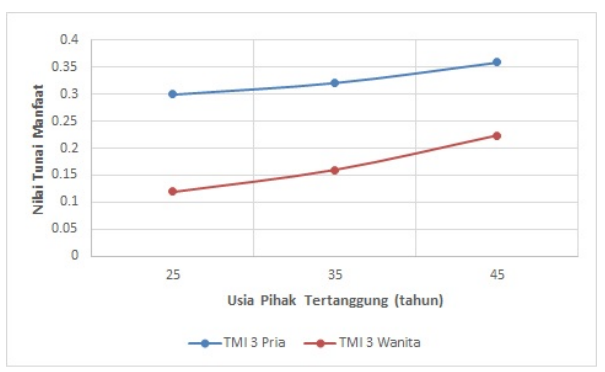

Gambar 2. Grafik nilai tunai manfaat untuk tingkat suku bunga konstan sebesar 5\% untuk pihak tertanggung berusia 25, 35, dan 45 tahun berdasarkan hukum mortalita Makeham.

Pada Gambar 2, dapat dilihat bahwa semakin tinggi usia peserta asuransi, nilai tunai manfaat yang diperoleh juga semakin tinggi. Jika dibandingkan dengan Gambar 1, nilai tunai manfaat berdasarkan hukum mortalita Makeham lebih tinggi dibandingkan dengan hasil perhitungan tanpa menggunakan hukum mortalita Makeham

\section{Nilai tunai Manfaat dengan Tingkat Suku Bunga Vasicek dan CIR}

Perhitungan nilai tunai manfaat dengan tingkat suku bunga Vasicek digunakan Persamaan 4.3 dan untuk tingkat suku CIR digunakan Persamaan 4.4 .

Berikut hasil perhitungan nilai tunai manfaat dengan tingkat suku bunga $V a$ sicek dapat dilihat pada Tabel 1 dan hasil perhitungan nilai tunai manfaat dengan tingkat suku bunga $C I R$ dapat dilihat pada Tabel 2.

Tabel 1. Hasil Perhitungan nilai tunai manfaat dengan tingkat suku bunga Vasicek.

\begin{tabular}{|c|c|c|c|c|c|c|c|c|}
\hline \multicolumn{3}{|c|}{ Parameter } & \multicolumn{3}{|c|}{ TMI 3 pria } & \multicolumn{3}{|c|}{ TMI 3 wanita } \\
\hline$a$ & 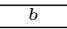 & $\sigma$ & $\mathrm{A} 25$ & A35 & $\mathrm{A} 45$ & A25 & A35 & $\mathrm{A} 45$ \\
\hline \multirow{9}{*}{1.1} & \multirow{3}{*}{0.055} & 0.01 & 0.12605 & 0.18970 & 0.28418 & 0.10344 & 0.15707 & 0.23603 \\
\hline & & 0.2 & 0.21937 & 0.29447 & 0.39340 & 0.19026 & 0.25676 & 0.34395 \\
\hline & & 0.35 & 0.78312 & 0.81084 & 0.83919 & 0.77005 & 0.79764 & 0.82573 \\
\hline & \multirow{3}{*}{0.07} & 0.01 & 0.07879 & 0.13027 & 0.21513 & 0.06177 & 0.10344 & 0.17125 \\
\hline & & 0.2 & 0.13138 & 0.19577 & 0.29036 & 0.10833 & 0.16281 & 0.24223 \\
\hline & & 0.35 & 0.43594 & 0.50743 & 0.58912 & 0.40509 & 0.47254 & 0.54938 \\
\hline & \multirow{3}{*}{0.08} & 0.01 & 0.05896 & 0.10311 & 0.18 & 0.04498 & $0.07 \mathrm{~s}$ & 0.14041 \\
\hline & & 0.2 & 0.09535 & 0.15157 & 0.24020 & 0.07620 & 0.12247 & 0.19464 \\
\hline & & 0.35 & 0.29983 & 0.37647 & 0.47089 & 0.26858 & 0.33848 & 0.42428 \\
\hline \multirow{9}{*}{2.0} & \multirow{3}{*}{0.055} & 0.01 & 0.50289 & 0.57310 & 0.65154 & 0.47213 & 0.53900 & 0.61354 \\
\hline & & 0.2 & 0.53263 & 0.59994 & 0.67 & 0.50288 & 0.567 & 0.63835 \\
\hline & & 0.35 & 0.60036 & 0.66000 & 0.72 & 0.57 & 0.63 & 0.69340 \\
\hline & \multirow{3}{*}{0.07} & 0.01 & 0.42227 & 0.49831 & 0.58625 & 0.38980 & 0.46110 & 0.54335 \\
\hline & & 0.2 & 0.44684 & 0.52124 & 0.60631 & 0.41480 & 0.48492 & 0.56491 \\
\hline & & 0.35 & 0.50275 & 0.57253 & 0.65 & 0.47215 & 0.53863 & 0.61271 \\
\hline & \multirow{3}{*}{0.08} & 0.01 & 0.37640 & 0.45454 & 0.54 & 0.34 & 0.416 & 0.50169 \\
\hline & & 0.2 & 0.398 & 0.4 & 0.56 & 0.36 & 0.43 & 0.52134 \\
\hline & & 0.35 & 0.44 & 0. & 0.60 & 0.41 & 0.48524 & 0.56488 \\
\hline \multirow{9}{*}{3.0} & \multirow{3}{*}{0.055} & 0.01 & & & 0.8 & & 0.75 & 0.79681 \\
\hline & & 0.2 & 0.73 & & 0.82 & 0.71768 & 0.75968 & 0.80322 \\
\hline & & 0.35 & 0.75 & 0.7 & 0.83 & 0.73682 & 0.77612 & 0.81666 \\
\hline & \multirow{3}{*}{0.07} & 0.01 & 0.672 & 0. & 0.7 & 0.6 & 0.69 & 0.75306 \\
\hline & & 0.2 & 0.68 & & & & 0.70 & 0.75907 \\
\hline & & & & & & 0. & 0.7 & 0.77167 \\
\hline & \multirow{3}{*}{0.08} & 0.01 & 0.63 & 0.6 & 0.75 & 0.61 & 0.66 & 0.72540 \\
\hline & & 0.2 & 0.64484 & 0.70037 & 0.75 & 0.61962 & 0.67367 & 0.73116 \\
\hline & & 0.35 & 0.66033 & 0.71373 & 0.77037 & 0.63598 & 0.68808 & 0.74324 \\
\hline
\end{tabular}


Tabel 2. Hasil Perhitungan nilai tunai manfaat dengan tingkat suku bunga CIR.

\begin{tabular}{|c|c|c|c|c|c|c|c|c|}
\hline \multicolumn{3}{|c|}{ Parameter } & \multicolumn{3}{|c|}{ TMI 3 pria } & \multicolumn{3}{|c|}{ TMI 3 wanita } \\
\hline$a$ & $b$ & $\sigma$ & A25 & A35 & A45 & A25 & A35 & A45 \\
\hline \multirow{9}{*}{1.1} & \multirow{3}{*}{0.055} & 0.01 & 0.08736 & 0.14152 & 0.22873 & 0.06917 & 0.11340 & 0.18377 \\
\hline & & 0.2 & 0.09021 & 0.14520 & 0.23309 & 0.07166 & 0.11668 & 0.18783 \\
\hline & & 0.35 & 0.09591 & 0.15248 & 0.24165 & 0.07665 & 0.12320 & 0.19581 \\
\hline & \multirow{3}{*}{0.07} & 0.01 & 0.05175 & 0.09274 & 0.16736 & 0.03900 & 0.07110 & 0.12836 \\
\hline & & 0.2 & 0.05365 & 0.09549 & 0.17098 & 0.04057 & 0.07342 & 0.13155 \\
\hline & & 0.35 & 0.05749 & 0.10098 & 0.17813 & 0.04375 & 0.07809 & 0.13790 \\
\hline & \multirow{3}{*}{0.08} & 0.01 & 0.03785 & 0.07173 & 0.13841 & 0.02774 & 0.05367 & 0.10332 \\
\hline & & 0.2 & 0.03930 & 0.07397 & 0.14156 & 0.02889 & 0.05551 & 0.10602 \\
\hline & & 0.35 & 0.04 & 0.07847 & 0.14 & 0.0 & 0.0 & 0.11141 \\
\hline \multirow{9}{*}{2.0} & \multirow{3}{*}{0.055} & 0.01 & 0.08718 & 0.14123 & 0.22826 & 0.06903 & 0.11316 & 0.18340 \\
\hline & & 0.2 & 0.08806 & 0.14237 & 0.22964 & 0.06980 & 0.11418 & 0.18467 \\
\hline & & 0.35 & 0.08987 & 0.14471 & 0.23243 & 0.07137 & 0.11626 & 0.18725 \\
\hline & \multirow{3}{*}{0.07} & 0.01 & 0.05134 & 0.09200 & 0.16603 & 0.03 & 0.07 & 0.12734 \\
\hline & & 0.2 & 0.05193 & 0.09 & 0.16 & & 0.0 & 0.12834 \\
\hline & & 0.35 & 0.05313 & 0.09460 & 0.16949 & 0.0 & 0.0 & 0.13038 \\
\hline & \multirow{3}{*}{0.08} & 0.01 & 0.03741 & 0.07087 & 0.13678 & 0.02741 & 0.05 & 0.10210 \\
\hline & & 0.2 & 0.03785 & 0.0 & 0.13 & 0.02 & 0.05 & 0.10294 \\
\hline & & 0.35 & 0.03876 & 0.07299 & 0.13979 & 0.02849 & 0.05476 & 0.10467 \\
\hline \multirow{9}{*}{3.0} & \multirow{3}{*}{0.055} & 0.01 & 0.08710 & 0.14111 & 0.22 & 0.0 & 0.1 & 0.18325 \\
\hline & & 0.2 & 0.08 & & 0.2 & & & 382 \\
\hline & & 0.35 & 0.08 & & 0.22 & & 0.114 & 0.18499 \\
\hline & \multirow{3}{*}{0.07} & 0.01 & 0.05117 & 0.09170 & 0.16549 & 0.03856 & 0.07029 & 0.12692 \\
\hline & & 0.2 & 0.05144 & 0.09208 & 0.16600 & 0.03878 & 0.07062 & 0.12737 \\
\hline & & 0.35 & 0.0 & 0.09287 & & & 0.0 & 0.12829 \\
\hline & \multirow{3}{*}{0.08} & 0.01 & & 0.0 & & & & 0.10160 \\
\hline & & 0.2 & 0.03743 & 0.07084 & 0.13656 & 0.02743 & 0.05303 & 0.10198 \\
\hline & & 0.35 & 0.03783 & 0.07148 & 0.13748 & 0.02776 & 0.05355 & 0.10276 \\
\hline
\end{tabular}

Dari Tabel 1 dan Tabel 2 dapat dilihat semakin tinggi usia peserta asuransi, nilai tunai manfaat yang diperoleh juga semakin tinggi. Untuk nilai tunai manfaat yang mengikuti model Vasicek, semakin besar nilai parameter $a$ dan $\sigma$, nilai tunai manfaat yang diperoleh juga semakin besar. Sedangkan untuk parameter $b$, semakin besar nilai parameter $b$, nilai tunai manfaat yang diperoleh semakin kecil. Untuk nilai tunai manfaat yang mengikuti model $C I R$, semakin besar nilai parameter $a$ dan $b$, nilai tunai manfaat yang diperoleh semakin kecil. Sedangkan untuk parameter $\sigma$, semakin besar nilai parameter $\sigma$, nilai tunai manfaat yang diperoleh semakin besar.

\section{Nilai Tunai Manfaat dengan Tingkat Suku Bunga Vasicek dan CIR berdasarkan Hukum Mortalita Makeham}

Hasil perhitungan nilai tunai manfaat dengan tingkat suku bunga Vasicek berdasarkan hukum mortalita Makeham dapat dilihat pada Tabel 3 dan hasil perhitungan nilai tunai manfaat dengan tingkat suku bunga $C I R$ berdasarkan hukum mortalita Makeham dapat dilihat pada Tabel 4.

Dari tabel 3 dan 4, dapat dilihat pengaruh usia peserta asuransi dan nilai parameter $a, b$, dan $\sigma$ pada hasil perhitungan nilai tunai manfaat dengan tingkat suku bunga Vasicek dan CIR berdasarkan hukum mortalita Makeham sama dengan hasil perhitungan tanpa menggunakan hukum mortalita Makeham pada Tabel 3 dan Tabel 4, hanya saja nilai manfaat dengan hukum mortalita Makeham lebih besar.

\section{Perhitungan Tingkat Error Nilai Tunai Manfaat}

Pada pendekatan hukum mortalita terhadap tabel mortalita tentu akan ada perbedaan pada nilai-nilainya. Demikian pula dengan nilai tunai manfaat asuransi jiwa seumur hidup. Oleh karena itu akan dihitung ketidaksesuaian pada nilai tunai manfaat asuransi jiwa seumur hidup untuk berbagai parameter dan usia pihak tertang- 
Penerapan Hukum Mortalita Makeham 79 Tabel 3. Hasil Perhitungan nilai tunai manfaat dengan tingkat suku bunga Vasicek berdasarkan hukum mortalita Makeham.

\begin{tabular}{|c|c|c|c|c|c|c|c|c|}
\hline \multicolumn{3}{|c|}{ Parameter } & \multicolumn{3}{|c|}{ TMI 3 pria } & \multicolumn{3}{|c|}{ TMI 3 wanita } \\
\hline $\bar{a}$ & $b$ & $\sigma$ & $\mathrm{A} 25$ & $\mathrm{~A} 35$ & $\mathrm{~A} 45$ & $\mathrm{~A} 25$ & A35 & $\mathrm{A} 45$ \\
\hline \multirow{9}{*}{1.1} & \multirow{3}{*}{0.055} & 0.01 & 0.33107 & 0.35493 & 0.39559 & 0.13955 & 0.18538 & 0.25459 \\
\hline & & 0.2 & 0.41905 & 0.44748 & 0.49115 & 0.22697 & 0.28436 & 0.36163 \\
\hline & & 0.35 & 0.83506 & 0.84600 & 0.85927 & 0.78086 & 0.80495 & 0.83014 \\
\hline & \multirow{3}{*}{0.07} & 0.01 & 0.27667 & 0.29592 & 0.33169 & 0.09560 & 0.13083 & 0.18951 \\
\hline & & 0.2 & 0.33542 & 0.35957 & 0.40037 & 0.14438 & 0.19098 & 0.26067 \\
\hline & & 0.35 & 0.58970 & 0.61730 & 0.65453 & 0.43526 & 0.49394 & 0.56262 \\
\hline & \multirow{3}{*}{0.08} & 0.01 & 0.24973 & 0.26629 & 0.298 & 0.07 & 0.106 & 0.15823 \\
\hline & & 0.2 & 0.29579 & 0.31682 & 0.35451 & 0.11087 & 0.15018 & 0.21300 \\
\hline & & 0.35 & 0.48395 & 0.51321 & 0.55552 & 0.30341 & 0.36399 & 0.44038 \\
\hline \multirow{9}{*}{2.0} & \multirow{3}{*}{0.055} & 0.01 & 0.64827 & 0.67546 & 0.71137 & 0.50104 & 0.55926 & 0.62595 \\
\hline & & 0.2 & 0.665 & 0.69587 & 0.73 & 0.53 & 0.58 & 0.65003 \\
\hline & & 0.35 & 0.717 & 0.74117 & 0.77 & 0.59736 & 0.64 & 0.70336 \\
\hline & \multirow{3}{*}{0.07} & 0.01 & 0.58781 & 0.61709 & 0.65704 & 0.42213 & 0.48411 & 0.55759 \\
\hline & & 0.2 & 0.60616 & 0.63486 & 0.67360 & 0.44609 & 0.50709 & 0.57858 \\
\hline & & 0.35 & 0.64720 & 0.67422 & 0.70990 & 0.50088 & 0.55877 & 0.62504 \\
\hline & \multirow{3}{*}{0.08} & 0.01 & 0.55237 & 0.58235 & 0.62413 & 0.37758 & 0.44055 & 0.51690 \\
\hline & & 0.2 & 0.56 & 0.59 & 0.63 & 0.3 & 0.46 & 0.53608 \\
\hline & & 0.35 & 0.60588 & 0.63447 & 0.6 & 0.44654 & 0.50 & 0.57849 \\
\hline \multirow{9}{*}{3.0} & \multirow{3}{*}{0.055} & 0.01 & & & & & 0.76 & 0.80372 \\
\hline & & 0.2 & 0.81708 & 0.83380 & 0.85441 & 0.73421 & 0.77086 & 0.80990 \\
\hline & & 0.35 & 0.82 & 0.84485 & 0.86402 & 0.75220 & 0.78 & 0.82285 \\
\hline & \multirow{3}{*}{0.07} & 0.01 & 0.7 & 0.79 & 0.8 & 0.66 & & 0.76143 \\
\hline & & 0.2 & 0.7 & 0.7 & 0.8 & 0.6 & 0.72 & 0.76723 \\
\hline & & 0.35 & 0.788 & 0.80 & & 0.6 & 0.73 & 0.77939 \\
\hline & \multirow{3}{*}{0.08} & 0.01 & 0.747 & 0.76924 & 0.79 & 0.63 & 0.68 & 0.73466 \\
\hline & & 0.2 & 0.752 & 0.77396 & 0.80 & 0.64158 & 0.68871 & 0.74022 \\
\hline & & 0.35 & 0.76302 & 0.78388 & 0.81012 & 0.65703 & 0.70246 & 0.75189 \\
\hline
\end{tabular}

Tabel 4. Hasil perhitungan nilai tunai manfaat dengan tingkat suku bunga $C I R$ berdasarkan hukum mortalita Makeham.

\begin{tabular}{|c|c|c|c|c|c|c|c|c|}
\hline \multicolumn{3}{|c|}{ Parameter } & \multicolumn{3}{|c|}{ TMI 3 pria } & \multicolumn{3}{|c|}{ TMI 3 wanita } \\
\hline $\bar{a}$ & 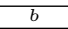 & $\sigma$ & $\mathrm{A} 25$ & A35 & $\mathrm{A} 45$ & $\mathrm{~A} 25$ & A35 & $\mathrm{A} 45$ \\
\hline \multirow{9}{*}{1.1} & \multirow{3}{*}{0.055} & 0.01 & 0.28735 & 0.30761 & 0.34453 & 0.10357 & 0.14106 & 0.20215 \\
\hline & & 0.2 & 0.29075 & 0.31132 & 0.34858 & 0.10622 & 0.14441 & 0.20623 \\
\hline & & 0.35 & 0.29742 & 0.31858 & 0.35649 & 0.11151 & 0.15105 & 0.21426 \\
\hline & \multirow{3}{*}{0.07} & 0.01 & 0.23887 & 0.25428 & 0.28515 & 0.07029 & 0.09712 & 0.14593 \\
\hline & & 0.2 & 0.24171 & 0.25743 & 0.28870 & 0.07207 & 0.09956 & 0.14919 \\
\hline & & 0.35 & 0.24731 & 0.26363 & 0.29570 & 0.07566 & 0.10445 & 0.15565 \\
\hline & \multirow{3}{*}{0.08} & 0.01 & 0.21538 & 0.22825 & 0.25545 & 0.05700 & 0.07847 & 0.12023 \\
\hline & & 0.2 & 0.21791 & 0.23106 & 0.25 & 0.05 & 0.086 & 0.12300 \\
\hline & & 0.35 & 0.22292 & 0.23663 & 0.26507 & 0.06117 & 0.08441 & 0.12853 \\
\hline \multirow{9}{*}{2.0} & \multirow{3}{*}{0.055} & 0.01 & 0.28683 & 0.30705 & 0.34390 & 0.10337 & 0.14078 & 0.20175 \\
\hline & & 0.2 & 0.28791 & 0.30823 & 0.34519 & 0.10419 & 0.14182 & 0.20303 \\
\hline & & 0.35 & 0.29011 & 0.31063 & 0.34 & 0.10587 & 0.143 & 0.20563 \\
\hline & \multirow{3}{*}{0.07} & 0.01 & 0.23720 & 0.25249 & 0.28 & 0.06976 & 0.096 & 0.14480 \\
\hline & & 0.2 & 0.23811 & 0.25350 & 0.28426 & 0.07031 & 0.09713 & 0.14582 \\
\hline & & 0.35 & 0.23996 & 0.25555 & 0.28 & 0.07145 & 0.09869 & 0.14791 \\
\hline & \multirow{3}{*}{0.08} & 0.01 & 0.21317 & 0.22589 & 0.25 & 0.05637 & 0.07759 & 0.11886 \\
\hline & & 0.2 & 0.21399 & 0.22679 & 0.25 & 0.05680 & 0.07820 & 0.11972 \\
\hline & & 0.35 & 0.2 & 0.2 & 0.2 & & 0.0 & 0.12150 \\
\hline \multirow{9}{*}{3.0} & \multirow{3}{*}{0.055} & 0.01 & $0.2 \varepsilon$ & 0.3 & 0.3 & 0.1 & 0.14 & 0.20158 \\
\hline & & 0.2 & 0.28 & 0.30735 & 0.34 & 0.10 & 0.141 & 0.20216 \\
\hline & & 0.35 & 0.288 & 0.30844 & 0.34 & 0.10 & 0.142 & 0.20334 \\
\hline & \multirow{3}{*}{0.07} & 0.01 & 0.236 & 0.25174 & 0.28 & 0.06 & 0.09 & 0.14434 \\
\hline & & 0.2 & 0.23 & 0.25 & & & 0.09 & 0.14480 \\
\hline & & 0.35 & 0.2 & 0.25 & & & 0.09 & 0.14574 \\
\hline & \multirow{3}{*}{0.08} & 0.01 & 0.212 & 0.22 & 0.25 & 0.05 & 0.077 & 0.11829 \\
\hline & & 0.2 & 0.212 & 0.22530 & 0.25 & 0.05630 & 0.07750 & 0.11868 \\
\hline & & 0.35 & 0.21337 & 0.22614 & 0.25310 & 0.05670 & 0.07807 & 0.11949 \\
\hline
\end{tabular}

gung dengan menggunakan relative error yaitu [8]:

$$
\text { Error }=\frac{\left|A_{x_{\text {Makeham }}}-A_{x_{\text {tabel }}}\right|}{A_{x_{\text {tabel }}}} \times 100 \%
$$

Dengan menggunakan Persamaan 6.1 diperoleh hasil perhitungan tingkat error nilai tunai manfaat sebagai berikut.

\section{Tingkat Error Nilai tunai Manfaat dengan Tingkat Suku Bunga Konstan}

Hasil perhitungan tingkat error nilai tunai manfaat dengan tingkat suku bunga konstan sebesar 5\% dapat dilihat pada Gambar 3. Dari Gambar 3 dapat dilihat bahwa semakin besar usia peserta asuransi, tingkat error nilai tunai manfaat yang diperoleh semakin kecil. 


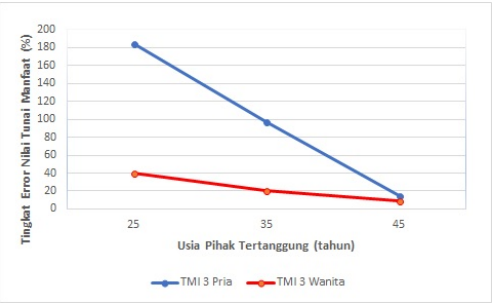

Gambar 3. Grafik tingkat error nilai tunai manfaat untuk tingkat suku bunga konstan sebesar 5\% untuk pihak tertanggung berusia 25, 35, dan 45 tahun.

\section{Tingkat Error Nilai tunai Manfaat dengan Tingkat Suku Bunga Vasicek} dan $C I R$

Berikut hasil perhitungan tingkat error nilai tunai manfaat dengan tingkat suku bunga Vasicek dan CIR yang dapat dilihat pada Tabel 5 dan Tabel 6 .

Tabel 5. Hasil perhitungan tingkat error nilai tunai manfaat dengan tingkat suku bunga Vasicek

\begin{tabular}{|c|c|c|c|c|c|c|c|c|}
\hline \multicolumn{3}{|c|}{ Parameter } & \multicolumn{3}{|c|}{ TMI 3 pria } & \multicolumn{3}{|c|}{ TMI 3 wanita } \\
\hline $\bar{a}$ & $b$ & $\sigma$ & $\mathrm{A} 25$ & A35 & A45 & A25 & A35 & A45 \\
\hline \multirow{9}{*}{1.1} & \multirow{3}{*}{0.055} & 0.01 & 162.65290 & 87.09885 & 39.20508 & 34.90834 & 18.02255 & 7.86359 \\
\hline & & 0.2 & 91.02633 & 51.96134 & 24.84763 & 19.29357 & 10.74782 & 5.13930 \\
\hline & & 0.35 & 6.63255 & 4.33672 & 2.39282 & 1.40446 & 0.91747 & 0.53355 \\
\hline & \multirow{3}{*}{0.07} & 0.01 & $\frac{0.05200}{251.15612}$ & 127.17010 & 54.18133 & $\begin{array}{l}1.40440 \\
54.76969\end{array}$ & 26.47763 & 10.66276 \\
\hline & & 0.2 & 155.30994 & 83.67056 & 37.88774 & 33.28021 & 17.30344 & 7.61425 \\
\hline & & 0.35 & 35.27052 & 21.65326 & 11.10358 & 7.44965 & 4.52999 & 2.40940 \\
\hline & \multirow{3}{*}{0.08} & 0.01 & 323.52774 & 158.25226 & 65.03205 & 71.37887 & 33.14603 & 12.69049 \\
\hline & & 0.2 & 210.20551 & 109.02768 & 47.58838 & 45.50133 & 22.62353 & 9.43021 \\
\hline & & 0.35 & 61.40941 & 36.32234 & 17.97177 & 12.96841 & 7.53780 & 3.79435 \\
\hline \multirow{9}{*}{2.0} & \multirow{3}{*}{0.055} & 0.01 & 28.90875 & 17.86007 & 9.18310 & 6.12429 & 3.75914 & 2.02246 \\
\hline & & $\frac{0.01}{0.2}$ & 25.74645 & 15.99124 & 8.26437 & 5.45788 & 3.37213 & 1.82896 \\
\hline & & 0.35 & $\frac{25.44040}{19.58517}$ & $\frac{15.99124}{12.29867}$ & $\frac{8.20431}{6.42475}$ & $\frac{0.40808}{4.15847}$ & $\frac{3.31213}{2.60419}$ & $\frac{1.02690}{1.43621}$ \\
\hline & \multirow{3}{*}{0.07} & 0.01 & 39.20394 & 23.83734 & 12.07531 & 8.29288 & 4.99078 & 2.62089 \\
\hline & & 0.2 & 35.65520 & 21.79742 & 11.09863 & 7.54483 & 4.57093 & 2.42007 \\
\hline & & 0.35 & 28.73221 & 17.76144 & 9.14001 & 6.08613 & 3.73795 & 2.01256 \\
\hline & \multirow{3}{*}{0.08} & 0.01 & 46.74878 & 28.11844 & 14.10162 & 9.88411 & 5.86953 & 3.03254 \\
\hline & & $\frac{0.01}{0.2}$ & 42.92204 & 25.95900 & 13.08597 & 9.07635 & 5.42625 & 2.82664 \\
\hline & & 0.35 & 35.45009 & 21.68274 & 11.04714 & 7.50091 & 4.54676 & 2.40887 \\
\hline \multirow{9}{*}{3.0} & \multirow{3}{*}{0.055} & 0.01 & 11.29955 & 7.19893 & 3.80958 & 2.40902 & 1.53685 & 0.86730 \\
\hline & & 0.2 & 10.80169 & 6.88901 & 3.64961 & 2.30338 & 1.47134 & 0.83166 \\
\hline & & 0.35 & 9.78472 & 6.25419 & 3.32111 & 2.08744 & 1.33696 & 0.75823 \\
\hline & \multirow{3}{*}{0.07} & 0.05 & $\frac{9.18412}{14.78125}$ & $\frac{0.20419}{9.35362}$ & $\frac{3.02111}{4.91706}$ & $\frac{2.08144}{3.14623}$ & $\frac{1.53096}{1.99034}$ & $\frac{0.0020}{1.11150}$ \\
\hline & & 0.2 & 14.25601 & 9.03058 & 4.75219 & 3.03506 & 1.92245 & 1.07529 \\
\hline & & 0.35 & 13.18300 & 8.36883 & 4.41 & 2.80784 & 1.78321 & 1.00069 \\
\hline & \multirow{3}{*}{0.08} & 0.01 & 17.20783 & 10.84030 & 5.67402 & 3.65907 & 2.30180 & 1.27650 \\
\hline & & 0.2 & 16.66364 & 10.50830 & 5.50586 & 3.54405 & 2.23228 & 1.23990 \\
\hline & & 0.35 & 15.55183 & 9.82815 & 5.16047 & 3.30895 & 2.08968 & 1.16450 \\
\hline
\end{tabular}

Tabel 6. Hasil perhitungan tingkat error nilai tunai manfaat dengan tingkat suku bunga $C I R$

\begin{tabular}{|c|c|c|c|c|c|c|c|c|}
\hline \multicolumn{3}{|c|}{ Parameter } & \multicolumn{3}{|c|}{ TMI 3 pria } & \multicolumn{3}{|c|}{ anita } \\
\hline$a$ & $b$ & $\sigma$ & A25 & A35 & A45 & A25 & A35 & A45 \\
\hline \multirow{9}{*}{1.1} & \multirow{3}{*}{0.055} & 0.01 & 228.93898 & 117.36521 & 50.63070 & 49.73225 & 24.39301 & 10.00006 \\
\hline & & 0.2 & 222.29080 & 114.40528 & 49.54739 & 48.23058 & 23.76534 & 9.79774 \\
\hline & & 0.35 & 210.08898 & 108.93313 & 47.52646 & 45.48265 & 22.60753 & 9.42025 \\
\hline & \multirow{3}{*}{0.07} & 0.01 & 361.55516 & 174.17831 & 70.38325 & 80.21129 & 36.59381 & 13.69365 \\
\hline & & 0.2 & 350.50599 & 169.58292 & 68.85687 & 77.63693 & 35.59633 & 13.40706 \\
\hline & & 0.35 & 330.19911 & 161.08421 & 66.00439 & 72.92017 & 33.75593 & 12.87212 \\
\hline & \multirow{3}{*}{0.08} & 0.01 & 468.96624 & 218.19307 & 84.56821 & 105.46340 & 46.20634 & 16.36845 \\
\hline & & 0.2 & 454.54520 & 212.35899 & 82.74053 & 102.04861 & 44.92523 & 16.02217 \\
\hline & & 0.35 & 427.95200 & 201.5 & 79. & & 42.55 & 500 \\
\hline \multirow{9}{*}{2.0} & & 0.01 & 229.02081 & 117.41625 & 50.65843 & 49.74815 & 24.40248 & 10.00473 \\
\hline & \multirow{2}{*}{0.055} & 0.2 & 226.94417 & 116.49178 & 50.31992 & 49.27901 & 24.20647 & 9.94156 \\
\hline & & 0.35 & 222.81130 & 114.64778 & 49.64281 & 48.34622 & 23.81577 & 9.81519 \\
\hline & \multirow{3}{*}{0.07} & 0.01 & 362.01241 & 174.45552 & & 80.30394 & 36.64670 & 13.71783 \\
\hline & & 0.2 & 358.55432 & 173.01 & 70.0 & 79.49818 & 36.33 & 2795 \\
\hline & & 0.35 & 351.6 & 170 & 69 & 36 & 35.71 & 4815 \\
\hline & \multirow{3}{*}{0.08} & 0.01 & 469 & 218 & & 105.64578 & 46.30701 & 16.41187 \\
\hline & & 0.2 & 465.31 & 216.878 & 84.23 & 104.57633 & 45.90506 & 16.30296 \\
\hline & & 0.35 & 456.31488 & 213.22376 & 83.08325 & 102.44639 & 45.10337 & 16.08503 \\
\hline \multirow{9}{*}{3.0} & \multirow{3}{*}{0.055} & 0.01 & 229.04457 & 117.43127 & & 49.75273 & 24.40525 & 10.00612 \\
\hline & & 0.2 & & & & & 24.3 & 782 \\
\hline & & 0.35 & 226.223 & 116.174 & 50. & 49.11551 & 24.13882 & 9.92015 \\
\hline & \multirow{3}{*}{0.07} & 0.01 & 362.14876 & 174.53907 & 70.56304 & 80.33150 & 36.66259 & 13.72519 \\
\hline & & 0.2 & 360.59842 & 173.89323 & 70.34817 & 79.97027 & 36.52248 & 13.68486 \\
\hline & & 0.35 & 357.44 & 172 & & & 36.23 & 271 \\
\hline & \multirow{3}{*}{0.08} & 0.0 & & & & & 46.3 & 16.42519 \\
\hline & & 0.2 & 468.06879 & 218.04577 & 84.62469 & 105.22097 & 46.15715 & 16.37628 \\
\hline & & 0.35 & 463.94986 & 216.37309 & 84.09871 & 104.24600 & 45.79025 & 16.27663 \\
\hline
\end{tabular}

Dari Tabel 5 dan Tabel 6 dapat dilihat bahwa pengaruh tingkat suku bunga 
jangka panjang $(b)$ dan volatilitas suku bunga $(\sigma)$ untuk model Vasicek dan $C I R$ sama. Semakin besar nilai $b$, tingkat error dari nilai tunai manfaat juga semakin besar dan semakin besar nilai $\sigma$, tingkat error dari nilai tunai manfaat semakin kecil. Sedangkan pengaruh kecepatan penyesuaian suku bunga terhadap tingkat suku bunga jangka panjang (a) untuk model Vasicek dan CIR berbeda. Pada model Vasicek, semakin besar nilai $a$, tingkat error dari nilai tunai manfaat semakin kecil. Sedangkan pada model $C I R$, semakin besar nilai $a$, tingkat error dari nilai tunai manfaat semakin besar.

\section{Kesimpulan}

Dari hasil perhitungan dapat disimpulkan bahwa semakin tinggi usia seseorang, nilai tunai manfaat yang diperoleh semakin besar. Untuk nilai tunai manfaat yang mengikuti model Vasicek, semakin besar nilai parameter $a$ dan $\sigma$, nilai tunai manfaat yang diperoleh juga semakin besar. Sedangkan untuk parameter $b$, semakin besar nilai parameter $b$, nilai tunai manfaat yang diperoleh semakin kecil. Untuk nilai tunai manfaat yang mengikuti model $C I R$, semakin besar nilai parameter $a$ dan $b$, nilai tunai manfaat yang diperoleh semakin kecil. Sedangkan untuk parameter $\sigma$, semakin besar nilai parameter $\sigma$, nilai tunai manfaat yang diperoleh semakin besar. Untuk perhitungan nilai tunai manfaat yang diperoleh dengan menggunakan hukum mortalita Makeham lebih besar dibandingkan dengan menggunakan tabel mortalita Indonesia.

Tingkat error nilai tunai manfaat akan semakin kecil jika usia peserta asuransi semakin besar. Pengaruh parameter $b$ dan $\sigma$ untuk model Vasicek dan CIR terhadap tingkat error nilai tunai manfaat sama, yaitu semakin besar nilai parameter $b$, tingkat error yang diperoleh semakin besar dan semakin besar nilai parameter $\sigma$, tingkar error yang diperoleh semakin kecil. Sedangkan pengaruh parameter $a$ berbeda. Pada model Vasicek, semakin besar nilai parameter $a$, tingkat error dari nilai tunai manfaat semakin kecil, dan pada model $C I R$, semakin besar nilai parameter $a$, tingkat error dari nilai tunai manfaat semakin besar.

\section{Daftar Pustaka}

[1] Bowers, N.L., H.U. Gerber, J.C. Hickman, D.A. Jones, dan C.J. Nesbitt. 1997. Actuarial Mathematics. The Society of Actuaries, United States of America

[2] Futami, Takashi. 1993. Matematika Asuransi Jiwa Bagian I. Incorporated Foundation Oriental Life Insurance Cultural Development Center, Tokyo

[3] Huda, W., Devianto, D., Asdi, Y. 2013. Model Penyusutan Majemuk Jumlah Peserta Asuransi pada Asuransi Jiwa. Jurnal Matematika Unand, 2 (2): 99 107.

[4] Hull, J.C. 2003. Option, Futures, and Other Derivatives. Prentice Hall, New Jersey

[5] Jordan, Jr. C.W. 1991. Life Contingencies. The Society of Actuaries, Chicago

[6] Kamal, I., Devianto, D., dan Yanuar, F. 2014. Penentuan Premi Tahunan pada Asuransi Joint Life dengan Menggunakan Anuitas Reversionary. Jurnal Matematika Unand, 3 (4): 112 - 120.

[7] Rizki, M., Devianto, D., dan Yanuar, F. 2014. Kajian Metode Zillmer,Full 
Herliani Evinda, dkk.

Preliminary Term, dan Premium Sufficiency dalam Menentukan Cadangan Premi pada Asuransi Jiwa Dwiguna. Jurnal Matematika Unand, 3 (2): 160 167.

[8] Sanjaya, K.D., Permana, F.J., dan Kristiani, F. 2011. Perhitungan Nilai-nilai Aktuaria dengan Asumsi Tingkat Suku Bunga Berubah Secara Stokastik. Mat Sat, 11 (2): $149-152$. 